\title{
The effects of atorvastatin on pulmonary arterial hypertension and expression of p38, p27, and Jab1 in rats
}

\author{
YU-FEI GAO ${ }^{1 *}$, XIAO-DUO ZHU ${ }^{2 *}$, DONG-MEI SHI ${ }^{3}$, ZHI-CHENG JING ${ }^{4}, \mathrm{LI} \mathrm{LI}^{5}$, \\ DAN MA $^{1}$, ZHI-XIN FAN ${ }^{1}$, JIAN LI ${ }^{6}$, YI-WEI WANG ${ }^{1}$ and BING-XIANG WU ${ }^{1}$ \\ ${ }^{1}$ Cardiovascular Department, First Affiliated Hospital of Harbin Medical University; ${ }^{2}$ Department of \\ Geriatric Cardiovascular Disease, Heilongjiang Province Hospital; ${ }^{3}$ Internal Medicine Department, \\ Second Heilongjiang Province Hospital; ${ }^{4}$ Shanghai Pulmonary Hospital, Tongji University School \\ of Medicine; ${ }^{5}$ Medical Examination Center, First Affiliated Hospital of Harbin Medical University; \\ ${ }^{6}$ Cardiovascular Department, Longnan Hospital of Daqing City, Heilongjiang Province, P.R. China
}

Received April 30, 2010; Accepted June 4, 2010

DOI: $10.3892 /$ ijmm_00000497

\begin{abstract}
Statins have recently come under evaluation for the treatment of pulmonary arterial hypertension (PAH). The aim of this study was to examine the effects of atorvastatin on the clinical manifestations and expression of p38, p27 and Jab1 using a rat PAH model. Ninety-six male Wistar rats were divided into control (receiving no surgical treatment), vehicle and treatment groups, among which the last two groups underwent left pneumonectomy and were then treated with monocrotaline (MCT, $60 \mathrm{mg} / \mathrm{kg}$ ). Both control and vehicle groups subsequently received saline, and the treatment group received atorvastatin $(20 \mathrm{mg} / \mathrm{kg})$ by stomach catheter. Rats were sacrificed, and mean pulmonary arterial pressure (mPAP) and right ventricle hypertrophy index (RVHI) were measured.
\end{abstract}

Correspondence to: Dr Bing-Xiang Wu, Cardiovascular Department, First Affiliated Hospital of Harbin Medical University, No. 23 of Youzheng Street, Nangang District, Harbin 150001, Heilongjiang, P.R. China

E-mail: wubingxiang1964@163.com

*Contributed equally

Abbreviations: ANGII, angiotensin II; AS, atorvastatin; ET-1, endothelin-1; HE, hematoxylin/eosin; HER-2/neu, human epidermal growth factor receptor 2/neuroglioblastoma derived; HMG-COA, 3hydroxy-3-methylglutaryl-coenzyme A; Jab1, Jun-activating domainbinding protein 1; MAPK, mitogen-activated protein kinase; MCT, monocrotaline; mPAP, mean pulmonary arterial pressure; NBT/BCIP, nitro blue tetrazolium chloride/5-bromo-4-chloro-3-indolyl phosphate; PAH; pulmonary arterial hypertension; PDE5, phosphodiesterase Type 5; PNX, pneumonectomy; PVDF, polyvinylidene fluoride; RIPA, radioimmunoprecipitation assay; RVHI, right ventricle hypertrophy index; SDS-PAGE, sodium dodecyl sulfate polyacrylamide gel electrophoresis; TBST, Tris-buffered saline/Tween-20; TXA2, thromboxane A2

Key words: atorvastatin, pulmonary arterial hypertension, p38, p27, Jab1
The expression of p38, p27, and Jab1 was evaluated by immunohistochemistry and Western blotting. At 28 days, mPAP and RVHI and expression levels of Jab1 and p38 in the vehicle group were significantly higher than those in the treatment and control groups. However, the expression of p27 was lowest in the vehicle group among the three groups. Atorvastatin reduced PAP and RVHI in the rat PAH model, decreased expression of $\mathrm{p} 38$ and Jab1 but increased expression of $\mathrm{p} 27$.

\section{Introduction}

Pulmonary arterial hypertension (PAH) comprises a variety of disorders, all of which are characterized by an increase in pulmonary vascular resistance that results in an increase in blood pressure in the pulmonary arteries and workload in the right ventricle $(1,2)$. The early pathologic changes of PAH include obliteration of the lumen of the arteriolae, medial hypertrophy of the pulmonary arteries, sustained pulmonary vasoconstriction, and proliferation of pulmonary arterial endothelial cells. The main mechanism underlying PAH is proliferation of cells and reconstruction of pulmonary small vessels. The pathogenesis of PAH remains to be delineated, although environmental factors, genetic markers, and acquired external factors are thought to contribute to its development.

A variety of agents have been reported to improve the symptoms and life expectancy of patients with PAH. Controlled clinical trials have demonstrated the beneficial effects of several drug classes, including calcium channel blockers, prostanoids, endothelin receptor antagonists, and phosphodiesterase Type 5 (PDE5) inhibitors (3). Unfortunately, calcium channel blockers are not effective in reducing PAH in the majority of patients $(90 \%)$ (4). Prostanoids are potent vasodilators (5), but problems with adverse effects and drug delivery have limited their use. Endothelin receptor agonists improve exercise capacity and delay clinical worsening, and PDE5 inhibitors appear promising. However, none of the currently available therapeutic agents is able to cure the disease or reverse the vascular remodeling found in advanced PAH. Because various mechanisms may be responsible for the 


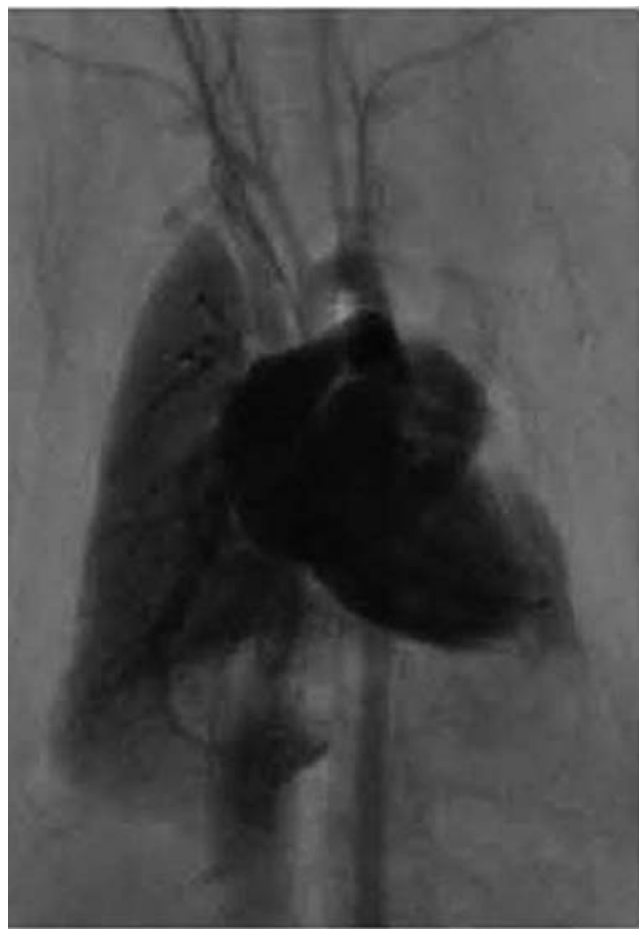

Figure 1. X-ray image of rat after left pneumonectomy.

pathogenesis, it is thought that combination therapy with agents that target multiple pathways will have the best results (6).

Among the agents that have recently come under evaluation for the treatment of PAH are 3-hydroxy-3-methylglutarylcoenzyme A (HMG-CoA) reductase inhibitors (statins). Statins block the conversion of HMG-CoA to mevalonate and, therefore, dramatically reduce the synthesis of cholesterol. Clinically, statins have been widely used to treat hypercholesterolemia. However, accumulated data suggest that statins improve cardiovascular outcomes not only by lowering cholesterol but through other beneficial effects on the vascular wall $(7,8)$. Statins improve endothelial function $(9)$, promote angiogenesis (10) and apoptosis (11-14), and reduce inflammation and pulmonary vascular remodeling (8). Statins may also act as antioxidants and antiproliferative $(15,16)$ and antithrombolytic agents by inhibiting the formation of microthrombi and inhibiting endothelin-1 (ET-1), angiotensin (ANGII), and thromboxane A2 (TXA2) (17).

In order to unravel the effects of statins on the complex network of signaling pathways that contribute to PAH, we evaluated the effects of atorvastatin (AS), a third generation statin, on PAH induced by left pneumonectomy and monocrotaline (MCT) in a rat model. The corresponding changes in the expression of signaling factors (i.e., p27, p38, and Jab1) were measured subsequently.

\section{Materials and methods}

Animals and pneumonectomy (PNX) procedures. Ninety-six healthy, male, Wistar rats (weight, 250-300 g) provided by the animal center in the First Affiliated Hospital of Ha Er Bing Medical University underwent left pneumonectomy as described by Nishimura et al (18). Rats were anesthetized with $1 \%$ sodium pentobarbital $(30 \mathrm{~m} / \mathrm{kg}$, i.p.) (Shanghai

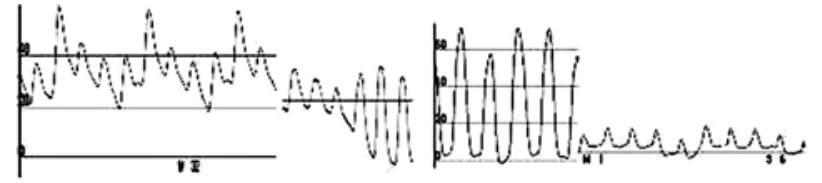

Figure 2. Mean pulmonary artery pressure measurements after left pneumonectomy. (A) Pulmonary artery; (B) cross part of pulmonary artery to right ventricle; (C) right ventricle; (D) right atrium.

Chemical Reagents, Shanghai, China) and given inhaled oxygen. Pneumonectomy was performed in the space between the third and fourth ribs of the left side. Rats were treated with antibiotics for 3 days after the pneumonectomy (Fig. 1). One week after the operation, rats were injected subcutaneously in the back with monocrotaline (MCT; $60 \mathrm{mg} / \mathrm{kg}$; SigmaAldrich, St. Louis, MO, USA). Animal experiments were conducted strictly according to the institutional guidelines.

Treatment groups. After pneumonectomy and MCT injection, 64 rats were randomized to receive atorvastatin $(20 \mathrm{mg} / \mathrm{kg})$ (Pfizer Pharmaceuticals Limited, Dalian, China H20030120, BH20030120) (treatment group) or saline (vehicle group) by daily oral gavage. An additional 32 rats (control group) did not undergo pneumonectomy, nor did they receive monocrotaline or AS. The control group received saline by stomach catheter ( $2 \mathrm{ml} /$ day).

Measurement of pulmonary arterial pressure (PAP) and right ventricle hypertrophy index (RVHI). At 7, 14, 21, and 28 days after injection of MCT, 8 rats from each group were anesthetized with $1 \%$ sodium pentobarbital $(30 \mathrm{mg} / \mathrm{kg}$, i.p.) and placed in a supine position. The neck skin was cut down, and the right internal jugular vein was dissected. A PV-1 pulmonary artery catheter (Medical School Physiology Research Institute of the Chinese Academy of Medical Sciences Foundation) filled with $0.1 \%$ heparin was inserted through an introducer under pressure with waveform monitoring using a P23ID Statham waveform monitor into the right internal jugular vein, the right atrium, right ventricle, and pulmonary artery and connected to a multi-channel physiologic recorder (Southern China Medical Technology Co, Ltd, Zhengzhou, China). The mPAP was recorded (Fig. 2), the rat was sacrificed, and the heart was weighed. Then the right and left ventricle plus the inter-ventricular septum were separated and weighed. The RVHI was defined as the weight of the right ventricle divided by the weight of the left ventricle plus the interventricular septum.

Immunohistochemistry. Lung tissue from the right inferior lobes of the sacrificed rats was fixed in $10 \%$ formalin, embedded in paraffin, and sectioned. The remaining tissue was frozen in liquid nitrogen and then kept at $-80^{\circ} \mathrm{C}$ for later processing. The tissue sections were deparaffinized in xylene and then rehydrated in 95, 70, and 50\% ethanol. Slides were blocked with $10 \%$ goat serum for $10 \mathrm{~min}$. The primary antibody against Jab1 (monoclonal antibody, Santa Cruz Biotechnology Inc., Santa Cruz, CA), p38, p27, or B-actin (Beijing Zhongshan Biological Techniques Ltd., Beijing, China), was added and incubated at $4^{\circ} \mathrm{C}$ overnight (control 
Table I. The quantitative results of immunohistochemical staining.

A, Expression of mPAP

\begin{tabular}{rcccc}
\hline & Control & Vehicle & Treatment & Comparisons \\
\hline 7 days & $19.0(18-23)$ & $31.5(26-38)$ & $28.5(25-32)$ & $\mathrm{C}<\mathrm{V}^{\mathrm{a}}, \mathrm{C}<\mathrm{T}^{\mathrm{a}}$ \\
14 days & $19.5(18-23)$ & $33.5(31-38)$ & $32.0(28-37)$ & $\mathrm{C}<\mathrm{V}^{\mathrm{a}}, \mathrm{C}<\mathrm{T}^{\mathrm{a}}$ \\
21 days & $19.5(18-30)$ & $40.0(11-45)$ & $35.0(31-38)$ & $\mathrm{C}<\mathrm{V}^{\mathrm{a}}, \mathrm{C}<\mathrm{T}^{\mathrm{a}}, \mathrm{V}>\mathrm{T}^{\mathrm{a}}$ \\
28 days & $23.0(17-26)$ & $44.5(40-50)$ & $35.5(34-39)$ & $\mathrm{C}<\mathrm{V}^{\mathrm{a}}, \mathrm{C}<\mathrm{T}^{\mathrm{a}}, \mathrm{V}>\mathrm{T}^{\mathrm{a}}$ \\
\hline
\end{tabular}

\section{$\mathrm{B}$, Expression of RVHI}

\begin{tabular}{ccccc}
\hline & Control & Vehicle & Treatment & Comparisons \\
\hline 7 days & $0.25(0.21-0.32)$ & $0.34(0.29-0.35)$ & $0.32(0.29-0.36)$ & $\mathrm{C}<\mathrm{V}^{\mathrm{a}}, \mathrm{C}<\mathrm{T}^{\mathrm{a}}$ \\
14 days & $0.27(0.20-0.34)$ & $0.41(0.39-0.46)$ & $0.41(0.39-0.44)$ & $\mathrm{C}<\mathrm{V}^{\mathrm{a}}, \mathrm{C}<\mathrm{T}^{\mathrm{a}}$ \\
21 days & $0.28(0.21-0.34)$ & $0.62(0.53-0.67)$ & $0.58(0.50-0.61)$ & $\mathrm{C}<\mathrm{V}^{\mathrm{a}}, \mathrm{C}<\mathrm{T}^{\mathrm{a}}$ \\
28 days & $0.30(0.25-0.37)$ & $0.70(0.64-0.80)$ & $0.60(0.54-0.66)$ & $\mathrm{C}<\mathrm{V}^{\mathrm{a}}, \mathrm{C}<\mathrm{T}^{\mathrm{a}},{\mathrm{V}>\mathrm{T}^{\mathrm{a}}}$ \\
\hline
\end{tabular}

${ }^{a} \mathrm{P}<0.05$ indicates statistical significance; $\mathrm{C}$, control group; $\mathrm{V}$, vehicle group; $\mathrm{T}$, treatment group.

slides were treated with PBS instead of antibody). The slides were then incubated with the secondary antibody solution, alkaline phosphatase-conjugated goat anti-rabbit IgG (Beijing Zhongshan Biological Techniques Ltd, Beijing, China), for $30 \mathrm{~min}$ at $37^{\circ} \mathrm{C}$, stained with hematoxylin and eosin (HE) solution, and viewed under the light microscope. The immunochemical reactions with antibodies against p38, p27, and Jab1 appeared as brown spots. Locations and densities were captured by Motic Images Advanced 3.0/Olympus BX 41 (Japan). The results were computed from 8 samples in each group with 5 views for each sample and are reported as mean \pm SD.

Western blotting. Radioimmunoprecipitation assay buffer ( $1 \mathrm{ml}$ ) was added to $1 \mathrm{~g}$ of lung tissue. The tissue was homogenized, centrifuged at $10,000 \mathrm{x}$ for $40 \mathrm{~min}$ at $4^{\circ} \mathrm{C}$ and protein in supernatants was quantified with Coomassie Brilliant Blue G. We added $20 \mu \mathrm{l}$ of antibody elution buffer to $80 \mu \mathrm{l}$ of the supernatant, boiled for $5 \mathrm{~min}$, and removed $40 \mu \mathrm{g}$ of protein for electrophoretic separation by $15 \%$ SDS-PAGE. Bands were electrophoretically transferred to polyvinylidene fluoride (PVDF) membranes at $4^{\circ} \mathrm{C}$, and membranes were blocked with $2 \%$ bovine serum. TBS-T (Tris-buffered saline + Tween-20) solution and primary antibody were added at room temperature; and membranes were incubated at $4^{\circ} \mathrm{C}$ overnight, washed with TBS-T, incubated with secondary antibody for $2 \mathrm{~h}$, washed again, and stained in nitro blue tetrazolium chloride/ 5-bromo-4-chloro-3-indolyl phosphate (NBT/BCIP) for 5$10 \mathrm{~min}$. The strips were scanned using a Chemi Imager ${ }^{\mathrm{TM}} 40000$ low-light imaging system (Alpha Innotech Corporation, Beijing, China). All data were normalized against B-actin.

Statistical analysis. Continuous data were expressed by median (range). Outcomes were compared using Wilcoxon's ranksum test for two-by-two comparisons. Data were analyzed using SAS 9.0 (SAS Institute Inc., Cary, NC, USA), and a $\mathrm{P}<0.05$ was considered statistically significant.

\section{Results}

PAH induced by MCT after PNX. Rats with PAH induced by pneumonectomy and MCT (the vehicle group) had dull fur, slower reactions, shortness of breath, ate and defecated less, and were less active. They lost 10-20\% of their weight by 1 week after surgery and $40-50 \%$ after 4 weeks. Rats in the treatment group were generally in better condition than those in the vehicle group, whereas rats in the control group gained weight. In the vehicle group, the lungs of rats were grey-red in color, and the surface was rough with spotted hemorrhage. The condition of the lungs in the treatment group appeared to be intermediate between that in the vehicle and control groups.

AS inhibits development of PAH. After 21 days, rats in the vehicle and treatment groups exhibited obvious pulmonary hypertension and right ventricular hypertrophy, as shown in Fig. 1. As shown in Tables IA and IB, the mPAP and RVHI in these two groups were significantly higher than in the control group $(\mathrm{P}<0.01)$, but the mPAP and RVHI in the treatment group were lower than in the vehicle group $(\mathrm{P}<0.01, \mathrm{P}<0.05)$.

Attenuated remodeling of pulmonary arteries. In the control group, examination by light microscopy showed thin walls in the small arteries and normal lung structure (Fig. 3A). In the vehicle group, we observed endothelial edema in the small arteries (50-150 $\mu \mathrm{m})$, glassy degeneration, wall thickening, and lumen stenosis at 7 days. At 14 days, these changes had worsened and proliferation of fibroblastic and smooth muscle cells, accumulation of fibrosis, and abnormal pulmonary alveoli were apparent. By 28 days, cells had disappeared and muscular tissue had replaced normal lung tissue. In addition, proliferation of smooth muscle and fibroblastic cells, formation of new internal lamina, wall thickening, and lumen stenosis and blockage were observed (Fig. 3B-D). The arterial hypertrophy, lumen stenosis, and proliferation of smooth muscle cells in 


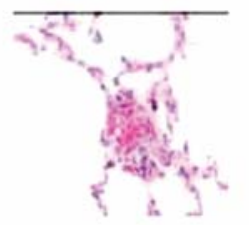

A

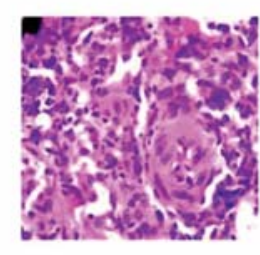

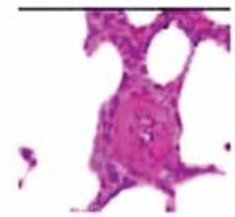

B

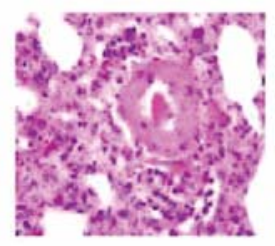

E

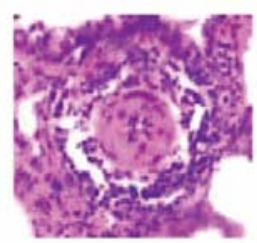

C

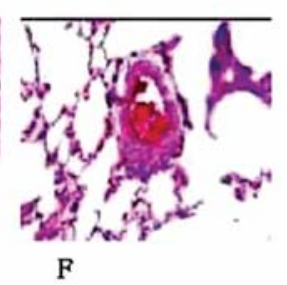

Figure 3. Light microscopic examination of lung tissue. (A) The arterial walls in the control group were thin (HE x200); (B-D) Arterial hypertrophy, lumen stenosis, and blockage were observed in the vehicle group (HE x400); (E-F) the diameters of the small arteries in the treatment group were larger than in the vehicle group (HE x200).
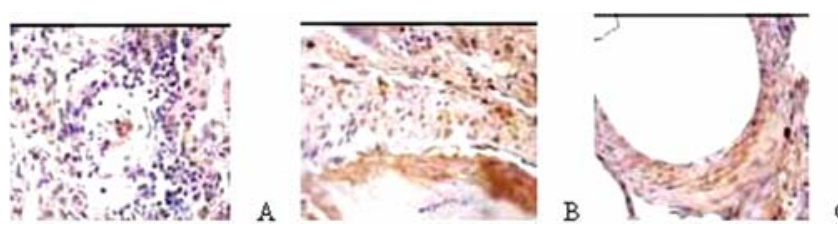

Figure 4. Immunohistochemical staining of Jab1. Lung tissue from the control group (A), vehicle group (B), and treatment group (C).

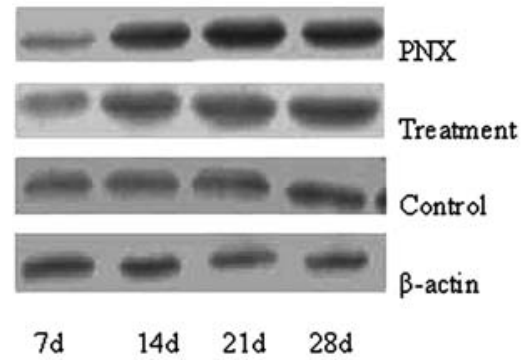

Figure 5. Western blot analysis of expression of Jab1 protein in lung tissue.

the treatment group were less severe than in the vehicle group (Fig. 3E and 3F).

AS inhibits expression of Jab1. Cells that expressed Jab1 were stained deeply in the cytosol by immunohistochemistry. As shown in Fig. 4A, there was little staining in the normal lung tissue from the control group. There was more staining in the tissue from the vehicle group (Fig. 4B) than in the control and the treatment groups (Fig. 4C). The quantitative analysis of the immunostaining results is shown in Table IIA, and the Western blot analysis is shown in Fig. 5 and Table IIIA. At 28 days, the expression of Jab1 was significantly higher in the vehicle group than in the control group $(\mathrm{P}<0.01)$. The treatment group expressed significantly more Jab1 than the control group $(\mathrm{P}<0.05)$ but, by day 14 , less than the vehicle group $(\mathrm{P}<0.05)$.

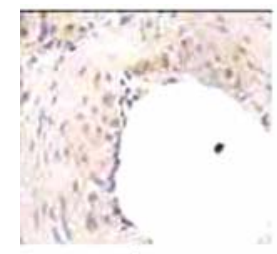

A

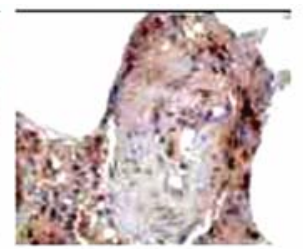

B

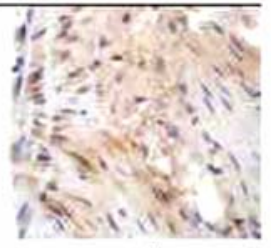

C
Figure 6. Immunohistochemical staining of p38. Lung tissue from the control group (A), vehicle group (B), and treatment group (C).

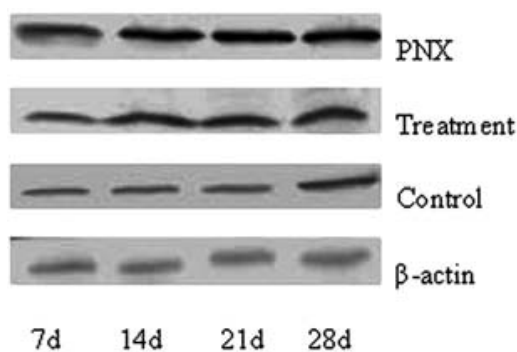

Figure 7. Western blot analysis of expression of p38 protein in lung tissue.
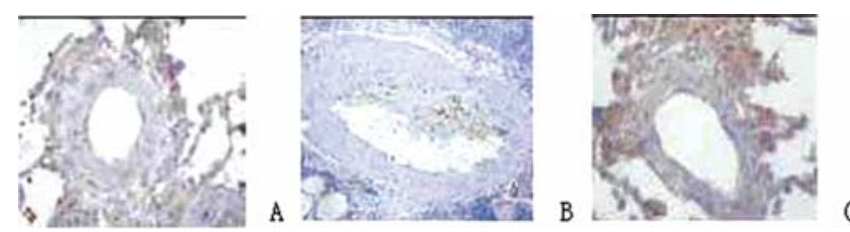

Figure 8. Immunohistochemical staining of p27. Lung tissue from the control group (A), vehicle group (B), and treatment group (C).

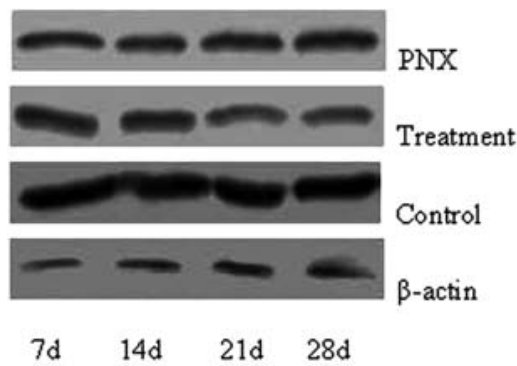

Figure 9. Western blot analysis of expression of p27 protein in lung tissue.

AS reduces activation of p 38 MAP kinase. The expression $\mathrm{p} 38$ in the vehicle group was also significantly higher than in the control group $(\mathrm{P}<0.01)$, as shown in Fig. 6A and 6B. However, the expression in the treatment group was again higher than in the control group $(\mathrm{P}<0.01)$ but lower than in the vehicle group $(\mathrm{P}<0.05)$ by 14 days (Fig. 6C, Table IIB). Western blot analysis confirmed these findings (Fig. 7 and Table IIIB).

AS increases expression of $p 27$. The rats with PAH induced by MCT expressed p27 at a lower level than those in the control group $(\mathrm{P}<0.05)$ (Fig. 8A and 8B). The expression of $\mathrm{p} 27$ in the rats from the treatment group was higher than in the vehicle group and lower than the control group (Fig. 8C, Table IIC). The Western blotting results also showed that 
Table II. The quantitative results of immunohistochemical staining.

A, Expression of Jab1

\begin{tabular}{|c|c|c|c|c|}
\hline & Control & Vehicle & Treatment & Comparisons \\
\hline 7 days & $16.0(13-22)$ & $25.5(21-29)$ & $25.0(17-31)$ & $\mathrm{C}<\mathrm{V}^{\mathrm{a}}, \mathrm{C}<\mathrm{T}^{\mathrm{a}}$ \\
\hline 14 days & $19.0(15-22)$ & $29.0(25-33)$ & $27.0(21-31)$ & $\mathrm{C}<\mathrm{V}^{\mathrm{a}}, \mathrm{C}<\mathrm{T}^{\mathrm{a}}$ \\
\hline 21 days & $19.0(16-23)$ & $36.5(31-41)$ & $29.0(24-34)$ & $\mathrm{C}<\mathrm{V}^{\mathrm{a}}, \mathrm{C}<\mathrm{T}^{\mathrm{a}}, \mathrm{V}>\mathrm{T}^{\mathrm{a}}$ \\
\hline 28 days & $18.5(14-24)$ & $41.5(38-50)$ & $29.5(25-36)$ & $\mathrm{C}<\mathrm{V}^{\mathrm{a}}, \mathrm{C}<\mathrm{T}^{\mathrm{a}}, \mathrm{V}>\mathrm{T}^{\mathrm{a}}$ \\
\hline
\end{tabular}

$\mathrm{B}$, Expression of p38

\begin{tabular}{ccccc}
\hline & Control & Vehicle & Treatment & Comparisons \\
\hline 7 days & $12.0(9-17)$ & $28.0(24-34)$ & $27.5(21-31)$ & $\mathrm{C}<\mathrm{V}^{\mathrm{a}}, \mathrm{C}<\mathrm{T}^{\mathrm{a}}$ \\
14 days & $13.5(11-18)$ & $38.0(32-45)$ & $35.5(30-40)$ & $\mathrm{C}<\mathrm{V}^{\mathrm{a}}, \mathrm{C}<\mathrm{T}^{\mathrm{a}}$ \\
21 days & $16.0(12-24)$ & $46.5(39-52)$ & $36.5(33-44)$ & $\mathrm{C}<\mathrm{V}^{\mathrm{a}}, \mathrm{C}<\mathrm{T}^{\mathrm{a}}, \mathrm{V}>\mathrm{T}^{\mathrm{a}}$ \\
28 days & $13.0(10-18)$ & $56.0(48-65)$ & $39.5(36-49)$ & $\mathrm{C}<\mathrm{V}^{\mathrm{a}}, \mathrm{C}<\mathrm{T}^{\mathrm{a}}, \mathrm{V}>\mathrm{T}^{\mathrm{a}}$ \\
\hline
\end{tabular}

C, Expression of p27

\begin{tabular}{rcccc}
\hline & Control & Vehicle & Treatment & Comparisons \\
\hline 7 days & $27.0(19-36)$ & $15.0(8-23)$ & $17.0(14-25)$ & $\mathrm{C}>\mathrm{V}^{\mathrm{a}}, \mathrm{C}>\mathrm{T}^{\mathrm{a}}$ \\
14 days & $25.5(21-32)$ & $16.5(14-19)$ & $18.0(16-22)$ & $\mathrm{C}>\mathrm{V}^{\mathrm{a}}, \mathrm{C}>\mathrm{T}^{\mathrm{a}}$ \\
21 days & $27.5(23-30)$ & $19.5(14-21)$ & $21.5(18-24)$ & $\mathrm{C}>\mathrm{V}^{\mathrm{a}}, \mathrm{C}>\mathrm{T}^{\mathrm{a}}$ \\
28 days & $28.0(21-36)$ & $19.5(15-24)$ & $23.0(18-27)$ & $\mathrm{C}>\mathrm{V}^{\mathrm{a}}$ \\
\hline
\end{tabular}

a $\mathrm{P}<0.05$ indicates statistical significance; $\mathrm{C}$, control group; $\mathrm{V}$, vehicle group; $\mathrm{T}$, treatment group.

expression of the $\mathrm{p} 27$ protein in the vehicle and treatment groups was significantly lower than that in the control group $(\mathrm{P}<0.01)$, but higher in the treatment group than the vehicle group $(\mathrm{P}<0.05)$ (Fig. 9, Table IIIC).

\section{Discussion}

The combination of left pneumonectomy and monocrotaline injection used in this study induced a condition in rats that exhibited the basic pathological signs of PAH (e.g., increased mean PAP, RVHI, pulmonary arterial hypertrophy, lumen stenosis, and proliferation of smooth muscle and fibroblastic cells). The excessive proliferation of cells resulted in the overgrowth of the internal lamina and smooth muscle cells in the small pulmonary arteries leading to increased vascular resistance. This stimulated endothelial cells to develop monoclonal multiplication, increased the vascular resistance further, and finally resulted in PAH (2).

In the subsequent experiments, we observed the highest mPAP and RVHI in rats with PAH (vehicle group), but both parameters were reduced in rats that received AS (treatment group). The results of immunohistochemistry and Western blotting indicated that the expression levels of Jab1 and p38 were also highest in the vehicle group, but they were reduced in the treatment group. By contrast, the expression of p27 was lowest in the vehicle group, with increasing levels of expression in the treatment group.
In previous studies using the rat model of MCT-induced $\mathrm{PAH}$, simvastatin was shown to reduce the PAH, reverse the proliferation of pulmonary arterial endothelium, inhibit the proliferation and migration of smooth muscle cells, mediate apoptosis, and attenuate the medial hypertrophy, fibrosis and cardiac hypertrophy $(18,19)$. Statins have been shown to inhibit the migration and proliferation of rat vascular smooth muscle cells (20). This inhibition of the proliferation of vascular cells by statins may be mediated by the $\mathrm{p} 27$ protein. Cellular proliferation in mammals is under strict regulation by $\mathrm{p} 27$, which is a negative regulator of the cell cycle that arrests the cells at G1 stage (21). In vascular smooth muscle cells, simvastatin increased the expression of p27 through the Rho pathway (22) and reduced DNA synthesis by $94 \%$.

p27 acts by binding to cyclin and cyclin-dependent kinase (Cdk), blocking the entry into S-phase mediated by the ubiquitin/proteasome and mitogen-activated protein kinases (MAPK) pathways. p38 is an important member of the MAPK family that can activate various transcription factors to regulate cellular proliferation, cell differentiation, and apoptosis (23). Miura et al (24) used JTT-705 to induce the phosphorylation of p38 in endothelial cells, which resulted in the upregulation of p27. Lu et al (25) have shown that using FR167653 to attenuate the p38 protein kinase activity could reduce pulmonary vascular remodeling in rats with monocrotalineinduced PAH. Yu et al (26) found that the expression of p27 increased and that of p38 decreased when rat hypoxic PAH 
Table III. The quantitative results of Western blot evaluation.

A, Expression of Jab1 protein

\begin{tabular}{rcccc}
\hline & Control & Vehicle & Treatment & Comparisons \\
\hline 7 days & $0.70(0.66-0.81)$ & $0.90(0.79-0.97)$ & $0.90(0.82-1.01)$ & $\mathrm{C}<\mathrm{V}^{\mathrm{a}}, \mathrm{C}<\mathrm{T}^{\mathrm{a}}$ \\
14 days & $0.81(0.69-0.86)$ & $1.12(1.04-1.25)$ & $1.09(1.03-1.24)$ & $\mathrm{C}<\mathrm{V}^{\mathrm{a}}, \mathrm{C}<\mathrm{T}^{\mathrm{a}}$ \\
21 days & $0.81(0.77-0.96)$ & $1.24(1.15-1.37)$ & $1.16(1.02-1.28)$ & $\mathrm{C}<\mathrm{V}^{\mathrm{a}}, \mathrm{C}<\mathrm{T}^{\mathrm{a}}$ \\
28 days & $0.91(0.79-0.95)$ & $1.39(1.29-1.54)$ & $1.21(1.12-1.27)$ & $\mathrm{C}<\mathrm{V}^{\mathrm{a}}, \mathrm{C}<\mathrm{T}^{\mathrm{a}}, \mathrm{V}>\mathrm{T}^{\mathrm{a}}$ \\
\hline
\end{tabular}

$\mathrm{B}$, Expression of $\mathrm{p} 38$ protein

\begin{tabular}{ccccc}
\hline & Control & Vehicle & Treatment & Comparisons \\
\hline 7 days & $0.63(0.59-0.67)$ & $0.69(0.66-0.76)$ & $0.71(0.67-0.76)$ & $\mathrm{C}<\mathrm{V}^{\mathrm{a}}, \mathrm{C}<\mathrm{T}^{\mathrm{a}}$ \\
14 days & $0.65(0.60-0.70)$ & $0.81(0.77-0.88)$ & $0.78(0.74-0.83)$ & $\mathrm{C}<\mathrm{V}^{\mathrm{a}}, \mathrm{C}<\mathrm{T}^{\mathrm{a}}$ \\
21 days & $0.73(0.62-0.75)$ & $0.98(0.93-1.12)$ & $0.86(0.79-0.88)$ & $\mathrm{C}<\mathrm{V}^{\mathrm{a}}, \mathrm{C}<\mathrm{T}^{\mathrm{a}}$ \\
28 days & $0.74(0.64-0.78)$ & $1.15(1.02-1.24)$ & $0.91(0.82-0.95)$ & $\mathrm{C}<\mathrm{V}^{\mathrm{a}}, \mathrm{C}<\mathrm{T}^{\mathrm{a}}, \mathrm{V}>\mathrm{T}^{\mathrm{a}}$ \\
\hline
\end{tabular}

C, Expression of p27 protein

\begin{tabular}{rcccc}
\hline & Control & Vehicle & Treatment & Comparisons \\
\hline 7 days & $0.68(0.60-0.78)$ & $0.42(0.32-0.49)$ & $0.45(0.38-0.54)$ & $\mathrm{C}>\mathrm{V}^{\mathrm{a}}, \mathrm{C}>\mathrm{T}^{\mathrm{a}}$ \\
14 days & $0.71(0.61-0.76)$ & $0.45(0.38-0.53)$ & $0.52(0.48-0.60)$ & $\mathrm{C}>\mathrm{V}^{\mathrm{a}}, \mathrm{C}>\mathrm{T}^{\mathrm{a}}, \mathrm{V}<\mathrm{T}^{\mathrm{a}}$ \\
21 days & $0.77(0.68-0.81)$ & $0.56(0.46-0.62)$ & $0.65(0.59-0.71)$ & $\mathrm{C}>\mathrm{V}^{\mathrm{a}}, \mathrm{C}>\mathrm{T}^{\mathrm{a}}, \mathrm{V}<\mathrm{T}^{\mathrm{a}}$ \\
28 days & $0.80(0.70-0.86)$ & $0.50(0.41-0.58)$ & $0.70(0.63-0.76)$ & $\mathrm{C}>\mathrm{V}^{\mathrm{a}}, \mathrm{C}>\mathrm{T}^{\mathrm{a}}, \mathrm{V}<\mathrm{T}^{\mathrm{a}}$ \\
\hline
\end{tabular}

${ }^{\mathrm{a}}<0.05$ indicates statistical significance; $\mathrm{C}$, control group; $\mathrm{V}$, vehicle group; $\mathrm{T}$, treatment group.

was treated with heparin. Our data showed that the expression of p38 was higher in the rats with PAH (vehicle group) and the expression of $\mathrm{p} 38$ in the AS treatment group became lower than the vehicle group 7 days after MCT injection.

Jab1 stands for c-Jun binding protein. The Jab1 proteins bind to the N-termini of c-Jun proteins. Sui et al (27) found that the expression of Jab1 was positively correlated with the severity of tumors and negatively correlated with the expression of p27 in patients with ovarian tumors. Tomoda et al (28) found that Jab1 functioned as an adaptor between p27 and the RNA transporter CRM1 that induced the nuclear export of p27 and its degeneration in the cytosol. We examined the expression of the Jab1 protein in our rat PAH model and found that it was significantly higher in the vehicle group compared with that in the control group $(\mathrm{P}<0.01)$. Jab1 in the treatment group was also higher than in the control group, but after 14 days, it was lower than in the vehicle group $(\mathrm{P}<0.05)$. The overall findings suggest that some of the effects of AS on PAH were mediated by counter-regulation between p38, Jab1, and $\mathrm{p} 27$.

We have evaluated the relationships among the clinical signs, mPAP and RVHI, and the expression of the three proteins (data not shown). At 28 days after the injection of MCT, there was a positive correlation among mPAP and RVHI, p38, and Jab1 ( $r=0.976,0.932$, and 0.934, respectively) and an inverse correlation with p27 ( $\mathrm{r}=-0.829)$ in the vehicle group, suggesting that mPAP was related to p27, p38, and Jab1.
After treatment with AS, mPAP remained positively correlated with RVHI, p38, and Jab1 ( $\mathrm{r}=0.934,0.927$, and 0.906, respectively) and inversely correlated with p27 ( $\mathrm{r}=-0.809)$.

The use of the animal model in this study has enabled us to examine several factors that may play a role in the underlying molecular mechanisms that lead to the development of PAH. It should be mentioned, however, that 28 days of treatment with AS did not restore the PAP or the protein levels of related signaling factors to normal in rats, nor did it completely reverse the RVHI and PAH. In addition, the clinical application of our results remains limited because there is currently no direct evidence that the rat model accurately reflects all aspects of the human disorders comprising the various types of PAH.

In summary, we have shown that AS reduced PAP and $\mathrm{RVHI}$ in the rat PAH model, decreased expression of p38 and Jab1, and increased expression of $\mathrm{p} 27$. We propose that the use of statins as one of multiple agents in a combination therapy approach to the treatment of $\mathrm{PAH}$ is a promising avenue for future research.

\section{Acknowledgements}

We are very grateful for the excellent help offered by Lic Long-Yan Li, Lic Jian-Tao Sun, Dr Rong-Sheng Xie, and Dr Jun-Xian Cao (the First Affiliated Hospital of Ha Er Bin Medical University). 


\section{References}

1. Galie N, Torbicki A, Barst R, et al: Guidelines on diagnosis and treatment of pulmonary arterial hypertension. Eur Heart J 25: 2243-2278, 2004.

2. Mandegar M, Fung YC, Huang W, Remillard CV, Rubin LJ and Yuan JX: Cellular and molecular mechanisms of pulmonary vascular remodeling: role in the development of pulmonary hypertension. Microvasc Res 68: 75-103, 2004.

3. Hoeper MM: Drug treatment of pulmonary arterial hypertension. Current and future agents. Drugs 65: 1337-1354, 2005.

4. Humbert M, Sitbon O and Simonneau G: Treatment of pulmonary arterial hypertension. N Engl J Med 351: 1425-1436, 2004.

5. Sitbon O, Humbert M, Nunes H, et al: Long-term intravenous epoprostenol infusion in primary pulmonary hypertension: prognostic factors and survival. J Am Coll Cardiol 40: 780-788, 2002.

6. Yuan JX and Rubin LJ: Pathogenesis of pulmonary arterial hypertension: the need for multiple hits. Circulation 111: 534-538, 2005.

7. Laufs U, Fata VL and Liao JK: Inhibition of 3-hydroxy-3methylglutaryl (HMG)-CoA reductase blocks hypoxia-mediated down-regulation of endothelial nitric oxide synthase. J Biol Chem 272: 31725-31729, 1997.

8. Takemoto M and Liao JK: Pleiotropic effects of 3-hydroxy-3methylglutaryl coenzyme a reductase inhibitors. Arterioscler Thromb Vasc Biol 21: 1712-1719, 2001.

9. Hernandez-Perera O, Perez-Sala D, Navarro-Antolin J, et al: Effects of the 3-hydroxy-3-methylglutaryl-CoA reductase inhibitors atorvastatin and simvastatin on the expression of endothelin-1 and endothelial nitric oxide synthase in vascular endothelial cells. J Clin Invest 101: 2711-2719, 1998.

10. Kureishi Y, Luo Z, Shiojima I, et al: The HMG-CoA reductase inhibitor simvastatin activates the protein kinase Akt and promotes angiogenesis in normocholesterolemic animals. Nat Med 6: 1004-1010, 2000.

11. Muller C, Kiehl MG, van de Loo J and Koch OM: Lovastatin induces p21WAF1/ Cip1 in human vascular smooth muscle cells: influences on protein phosphorylation, cell cycle, induction of apoptosis, and growth inhibition. Int J Mol Med 3: 63-68, 1999

12. Gurbanov E and Shiliang X: The key role of apoptosis in the pathogenesis and treatment of pulmonary hypertension. Eur J Cardiothorac Surg 30: 499-507, 2006.

13. Erl W, Hristov M, Neureuter M, Yan ZQ, Hansson GK and Weber PC: HMG-CoA reductase inhibitors induce apoptosis in neointima-derived vascular smooth muscle cells. Atherosclerosis 169: 251-258, 2003

14. Newton CJ, Xie YX, Burgoyne $\mathrm{CH}$, et al: Fluvastatin induces apoptosis of vascular endothelial cells: blockade by glucocorticoids. Cardiovasc Surg 11: 52-60, 2003.
15. Sato I, Ma L, Ikeda M, Morita I and Murota S: Simvastatin, a potent HMG-COA reductase inhibitor, inhibits the proliferation of human and bovine endothelial cells in vitro. J Atheroscler Thromb 4: 102-106, 1998.

16. Indolfi C, Cioppa A, Stabile E, et al: Effects of hydroxymethylglutaryl coenzyme A reductase inhibitor simvastatin on smooth muscle cell proliferation in vitro and neointimal formation in vivo after vascular injury. J Am Coll Cardiol 35: 214-221, 2000.

17. Almuti K, Rimawai R, Dpevack D and Ostfeld RJ: Effects of statins beyond lipid lowering: potential for clinical benefits. Int J Cardiol 109: 7-15, 2006.

18. Nishimura T, Faul JL, Berry GJ, et al: Simvastatin attenuates smooth muscle neointimal proliferation and pulmonary hypertension in rats. Am J Respir Crit Care Med 166: 1403-1408, 2002.

19. Nishimura T, Vaszar LT, Faul JL, et al: Simvastatin rescues rats from fatal pulmonary hypertension by inducing apoptosis of neointimal smooth muscle cells. Circulation 108: 1640-1645, 2003.

20. Kohno M, Shinomiya K, Abe S, et al: Inhibition of migration and proliferation of rat vascular smooth muscle cells by a new HMG-COA reductase inhibitor pitavastatin. Hypertens Res 25: 279-285, 2002.

21. Sherr CJ: Cancer cell cycles. Science 274: 1672-1677, 1996.

22. Laufs U, Marra D, Node K and Liao JK: 3-Hydroxy-3methylglutaryl-CoA reductase inhibitors attenuate vascular smooth muscle proliferation preventing rho GTPase-induced down-regulation of p27 (Kip1). J Biol Chem 274: 21926-21931, 1999.

23. Kyriakis JM and Avruch J: Sounding the alarm: protein kinase cascades activated by stress and inflammation. J Biol Chem 271: 24313-24316, 1996.

24. Miura S, Matsuo Y, Kawamura A, Saku K: JTT-705 blocks cell proliferation and angiogenesis through p38 kinase/p27 (kip1) and Ras/p21 (waf1) pathways. Atherosclerosis 182: 267-275, 2005.

25. Lu J, Shimpo H, Shimamoto A, et al: Specific inhibition of p38 mitogen-activated protein kinase with FR167653 attenuates vascular proliferation in monocrotaline-induced pulmonary hypertension in rats. J Thor Cardiovasc Surg 128: 850-859, 2004.

26. Yu L, Quinn DA, Garg HG and Hales CA: Gene expression of cyclin-dependent kinase inhibitors and effect of heparin on their expression in mice with hypoxia-induced pulmonary hypertension. Biochem Biophys Res Commun 345: 1565-1572, 2006.

27. Sui L, Dong Y, Ohno M, et al: Jab1 expression is associated with inverse expression of p27(kip1) and poor prognosis in epithelial ovarian tumors. Clin Cancer Res 7: 4130-4135, 2001.

28. Tomoda K, Kubota Y, Arata Y, et al: The cytoplasmic shuttling and subsequent degradation of p27Kip 1 mediated by Jab1/ CSN5 and the COP9 signalosome complex. J Biol Chem 277: 2302-2310, 2002 . 